\title{
THE TREND IN CONCENTRATION AND ITS IMPLICATIONS FOR SMALL BUSINESS
}

\author{
Gideon Rosenbluth*
}

\section{INTRODUCTION}

The controversy regarding the trend in concentration may be summarized in bald and oversimplified terms as follows: According to the extreme view on one side, both technology and the dynamics of business are making for increasing concentration. In one line of business after another, small firms are being displaced by giant corporate combines, so that the small independent businessman, the "entrepreneur" of classical economic theory, is gradually disappearing from the scene.

This view has a long history and can be traced back to Marx. More recently, it gained prominence and "respectability" in academic circles through the pioneering work of Berle and Means on the implications of the modern corporation: ${ }^{1}$

The typical business unit of the rgth century was owned by individuals or small groups; was managed by them or their appointees; and was, in the main, limited in size by the personal wealth of the individuals in control. These units have been supplanted in ever greater measure by great aggregations in which tens and even hundreds of thousands of workers and property worth hundreds of millions of dollars . . . are combined through the corporate mechanism. . . .

The trend, Berle and Means believed, was likely to continue: “. . . Every indication seems to be that the system will move forward to proportions which would stagger imagination today. ..."2

At the other end of the spectrum is the view that concentration has not increased since the turn of the century, and that both technology and the dynamics of business are constantly opening up new opportunities for small business. Great corporations exist, of course, but their relative importance in the economy has not increased over the last fifty years. "The extent of concentration shows no tendency to grow," writes Professor Adelman, "and it may possibly be declining. Any tendency either way, if it does exist, must be at the pace of a glacial drift." ${ }^{\text {"3 }}$ And Mr. Lilienthal points out that "one of the most attractive aspects of modern Big Business is that it creates opportunities previously nonexistent for a multitude of small business enterprises. . . ."

- B.A. I943, University of Toronto; Ph.D. 1953, Columbia University. Associate Professor of Economics, Queen's University at Kingston, Canada. Formerly Statistician, Government of Canada; Rescarch Associate, National Bureau of Economic Research. Author, Concentration in Canadian Manupacturino INDUSTRIES (1957). Contributor to economic publications.

I A. A. Berle, Jr. \& G. C. Means, The Modern Corporation and Private Property 2-3 (1932).

2Id. at $\mathrm{I}$.

${ }^{3}$ Adelman, The Measurement of Industrial Concentration, 33 Rev. Econ. \& STAT. 269, 295 (1951).

- David E. Lilienthil, Big Business: A New Era x (1953). 
In recent years, a good deal of research has been undertaken on the facts that are needed to determine which of these views is more nearly correct. The writer will try to answer this question by reviewing the statistical findings. A concluding section will outline the broader implications of the statistical trends that are observed.

\section{Small Business in Today's Economy}

According to the estimates of the Department of Commerce, there are today about 4,300,000 business firms in the United States or twenty-five to twenty-six per r,000 population. This figure excludes agriculture and the independent professions, which together account for about the same number of "business units." The Department of Commerce counts corporate subsidiaries as distinct business units, but the appropriate figure on a "consolidated" basis is not likely to differ by as much as 100,000. ${ }^{7}$ It may thus be estimated that including agriculture and the professions, there are roughly $8,500,000$ business firms, or fifty-one per $\mathrm{I}, 000$ of population.

The vast majority of these firms are "small business" within any reasonable definition of this term. In 1947, ninety-nine per cent of the business units, by Department of Commerce count, had less than roo employes, and ninety-five per cent had less than twenty employees. ${ }^{8}$ It is safe to assume that if firms are counted on a "consolidated" basis, the proportion of small firms is even higher. If agriculture and the professions are included, the proportion is obviously much higher still.

Table one shows that the predominance of small firms in the business population is characteristic of all industry groups. Firms with less than Ioo employees constitute ninety-nine per cent of all firms, or more, in retail and wholesale trade, service industries, the finance group, and construction. The lowest percentage is that for manufacturing, and even here, ninety-four per cent of the firms have less than Ioo employees.

There are, of course, no uniformly accepted standards as to what constitutes "small business," and many of those concerned with the problem would agree that size, measured on some absolute scale, should not be the only criterion. Most definitions, implicit and explicit, would, however, include a good many firms with over

'Survey of Current Business, Jan. 1958 , p. 6.

"In 1954, there were 3,900,000 farms in the United States (excluding "residential" farms, with sales of farm products of less than $\$ 250$ per year). Only 20,000 were operated by hired managers. In $x 955$, there were 3,800,000 self-employed workers in agriculture. U.S. DeP'T of Commerce, Statistical ABSTRACT OF THE UNited States 624, 630, 212 (1957) [hereinafter cited as Statistical Abstract].

The Census lists 600,000 self-employed professionals, 4 U.S. Bureau of the Census, Dep't of Conmerce, i950 Census of Population, Special Reports pt. I, c. B, table I2, iB-123 (1956); but many of these are members of partnerships. Data for 1954, published by the American Bar Foundation, suggest that about one-third of the lawyers in private practice are in partnerships. Statistical Abstract 148.

${ }^{7}$ U.S. Internal Revende Service, Statistics of Income, 1954, Corporation Income Tax Returns 123 (1957), show returns for I0,416 subsidiaries, for a year in which 80 per cent stock ownership was sufficient to permit the filing of a consolidated return. FTC, A List of rooo Large Manufacturing Companies ANd Their Subsidiaries, 1948 (195I) suggests that cases of controlling ownership of less than 80 per cent are relatively infrequent.

${ }^{8}$ Survey of Current Business, April I955, p. I9. 
roo employees in the "small-business" category. A review of legislative and administrative practice suggests that "cut-offs" of 250 or 500 employees have been frequently used. ${ }^{9}$

\section{TABLE I}

Distribution of Business Firms by Industry Group, 195I

\begin{tabular}{|c|c|c|}
\hline INDUSTRY GROUP & $\begin{array}{c}\text { Number of } \\
\text { FIRMS } \\
\text { (THOUSANDS) }\end{array}$ & $\begin{array}{l}\text { Percentage of } \\
\text { FIRMS WITH } \\
\text { LESS THAN } \\
\text { IOO EMPLOYEES }\end{array}$ \\
\hline 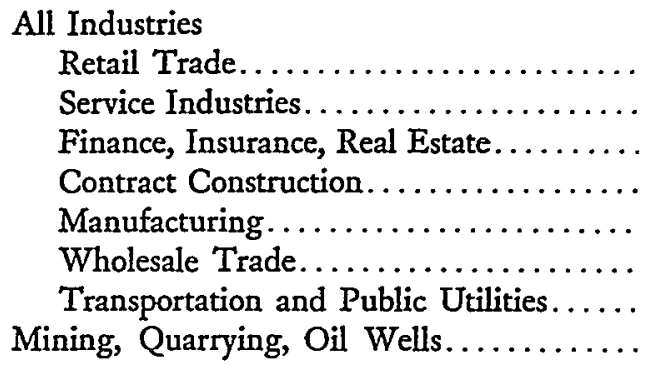 & $\begin{array}{r}4067 \\
1821 \\
733 \\
327 \\
377 \\
323 \\
269 \\
181 \\
37\end{array}$ & $\begin{array}{r}99 \\
\mathbf{a} \\
\mathbf{a} \\
99 \\
99 \\
94 \\
99 \\
98 \\
97\end{array}$ \\
\hline
\end{tabular}

a More than 99.5 per cent.

Source: Survey of Current Business, May 1954, pp. 18, 23.

We can, therefore, conclude that well over ninety-nine per cent of all firms, or between twenty-five and twenty-six per $r, 000$ of population, are "small business," even if we leave out of consideration agriculture and the professions. This finding gives us a standard by which to judge the trend in concentration.

The vast majority of business firms are not only small, they are also unincorporated. At a time when, according to the prediction of Berle and Means, the corporate system should have pretty well taken over the whole economy, eighty-seven per cent of all business firms, by Department of Commerce definition, are unincorporated; ${ }^{10}$ and the proportion of unincorporated units in agriculture and the professions is, of course, much higher. The proportion of incorporated firms is highly correlated with firm size. In 1947, eighty-three per cent of the firms with roo employees or more were incorporated, but less than eleven per cent of the smaller firms were. ${ }^{11}$

The economic importance of small firms is, of course, not adequately measured by their number. The major feature of the size structure of business firms is its extreme inequality, and in terms of any measure of size, small firms are much less important than their numerical predominance would suggest. Firms with $100 \mathrm{em}$ ployees or more, which constitute, as has been shown, only one per cent of the business population as defined by the Department of Commerce, nevertheless account

\footnotetext{
${ }^{\circ}$ House Select Committee on Small Business, Review of Small Business, H.R. Rep. No. 2513, 82d Cong., 2d Sess. 2-4 (1952).

${ }^{10}$ Survey of Current Business, April 1955, p. 15.

${ }^{12}$ Id. at 19 .
} 
for sixty per cent of the total employment in this sector. The small firms, which comprise ninety-nine per cent of the total, thus account for only forty per cent of employment. ${ }^{12}$ While the inequality of firm size varies a good deal from one industry group to another, it is very high in all of them. According to the Department of Commerce estimates, the top one per cent of firms in each industry group account for the following percentages of employment: $:^{13}$

$\begin{array}{lc}\text { Transportation and Public Utilities } & 79 \% \\ \text { Manufacturing } & 56 \% \\ \text { Finance, Insurance, Real Estate } & 55 \% \\ \text { Mining and Quarrying } & 52 \% \\ \text { Retail Trade } & 43 \% \\ \text { Service Industries } & 39 \% \\ \text { Contract Construction } & 35 \% \\ \text { Wholesale Trade } & 34 \% \\ \text { Manufacturing Subgroups } & \\ \text { Highest } \quad \text { Transportation Equipment } \\ \quad \text { Chemicals and Allied Products } \\ \quad \text { Petroleum and Coal Products } \\ \text { Lowest } \quad 74 \% \\ \quad \text { Textile Mill Products } \\ \quad \text { Paper and Products } \\ \text { Apparel and Related Products }\end{array}$

The degree of inequality is actually greater than these figures indicate, since a complete consolidation of the figures for corporate subsidiaries with those of their parent companies would undoubtedly raise the share of the "top one per cent." In the fields of trade, services, and construction (as well as agriculture and the professions), small firms account for the greater part of employment. In the other sectors of the economy, however, the bulk of employment is controlled by "large" firms. It is this great inequality of size that makes it possible to claim, at one and the same time, that the typical business firm is very small, and that the economy is dominated by large firms.

The relative importance of small business in the economy can also be investigated by examining the relative frequency of opportunities for self-employment. The Census of I950 shows 9,400,000 self-employed workers out of a total number of $55,800,000$, a proportion of seventeen per cent. This figure excludes self-employed managers of privately-held corporations, but a correction on this account would not raise the figure by as much as one percentage point. If farmers, farm managers, and farm laborers are excluded, the self-employed number 5,200,000 out of a total of 49,100,000 workers, or a proportion of eleven per cent. If professionals are also excluded, the figure is just over ten per cent. Thus, even in the nonagricultural

12 Survey of Current Business, May I954, p. x8. (Data for r946-5I.)

18 Id. at 20. (Data for I95I.) 
sector of the economy, outlets for the small businessman constitute more than onetenth of employment opportunities. ${ }^{14}$

\section{II}

\section{Trends in the Importance of Small Business}

Since at least ninety-nine per cent of all business firms are "small," large changes in the total number of firms can be taken as indicators of changes in the smallbusiness population. According to the Department of Commerce estimates, the number of business firms, excluding agriculture and the professions, rose from about $I, 500,000$ at the turn of the century to $3,000,000$ in $1929,3,300,000$ in $1940,4,000,000$ in I949, and 4,300,000 in 1957 . The rising trend was interrupted only during the Depression of the 'thirties, when the number of manufacturing firms shrank severely, and during World War II, when the main decline was in retail firms. The low points were $2,800,000$ in I933 and $2,900,000$ in 1943.

Per 1,000 of population, the number of small firms rose from about twenty-one at the turn of the century to twenty-five in I929 and 1940, and twenty-seven in 1949. Since then, it has fallen slightly to twenty-five in 1957. Thus, the number of small business outlets in the nonagricultural sector has increased, per head of population, since the turn of the century and has not declined below the level of the 'twenties. ${ }^{15}$

In agriculture, the trend has been very different. The number of farms (all types) fell from $6,400,000$ in I9I0 and I920 to $6,300,000$ in $1930,6,100,000$ in I940, $5,400,000$ in 1950 , and $4,800,000$ in 1954 . There has been, thus, a drastic decline since the interwar period, and the decline in relation to population is of longer standing. Per 1,000 of population, the number of farms fell from sixty-nine in Igro to sixty-one in I920, fifty-one in 1930 , thirty-six in $195^{\circ}$, and thirty in $1954^{10}$

If the results for the agricultural and nonagricultural sectors of the economy are combined, it is clear that in relation to population, the number of small "firms" has declined over the last fifty years. It is equally clear, however, that this outcome is entirely due to the decline in the relative importance of agriculture, combined with a trend towards increased concentration in this sector. In the nonagricultural branch of the economy, the numerical importance of small business has increased since 1900, and it has at least held its own since r929.

It may, however, be rash to interpret the increase in the relative number of small firms in the nonagricultural sector as representing an increase in significant opportunities for the small businessman. The average life span of a small business is notoriously short, mainly owing to the very high rate of "infant mortality." If the life expectancy of small firms has decreased significantly over the long run, the

${ }^{14} 4$ U.S. Bureau of the Census, op. cit. supra note 6, pt. I, c. B, table 12, 1B-123. The total number of corporations in 1950 was 500,000. Survey of Current Business, April 1955, p. 18. If we count one self-employed businessman for each corporation, which is most likely too much, the percentage would rise by just one point.

${ }_{15}^{15}$ Survey of Current Business, Jan. 1954, p. 12; id., Jan. 1958, p. 6.

${ }^{20}$ Statistical Abstract 5, 630. 
rise in the relative number of firms would indicate a rise in the relative number of optimists rather than opportunities. The rate of business turnover should, therefore, be investigated.

There is no reliable historical information on a comprehensive basis regarding the rate of turnover among small firms. Some light is, however, thrown on this matter by the records of Dun and Bradstreet. Their listing of business firms, while incomplete, appears to cover between one-half and two-thirds of the number estimated by the Department of Commerce. Hence, we can be sure that at least ninetyeight per cent of their firms are "small." The number of firm names annually deleted from their list gives an indication of the rate of turnover, although it reflects transfers of ownership and disappearance of a firm through merger, as well as discontinued businesses. The percentage of "deletions" in the Dun and Bradstreet listing averaged between twenty and twenty-one per cent in the first three decades of the century, but fell to eighteen per cent in the late 'thirties and seventeen per cent in the 'forties. ${ }^{17}$

For the 'forties and 'fifties, Department of Commerce estimates are available. The percentage of firms "discontinued" and "transferred" (roughly comparable to the Dun and Bradstreet "deletions") was sixteen per cent in $195^{0}-56$. Omitting transfers, the percentage of firms discontinued was eight per cent in the 'forties and 7.6 per cent in $1950-56 .^{18}$

The limited evidence that is available thus suggests that there has not been any long-run tendency towards increased mortality among small firms. In fact, the opposite trend is suggested by the figures. We may conclude that in the nonagricultural sector of the economy, the opportunities for small business have not contracted, but have, on the contrary, tended to expand over the last fifty years. This expansion has not, however, been sufficient to offset the decline in the number of farms.

\section{III}

\section{The Trend in Concentration}

It is evident that whatever the trend in concentration may have been in the twentieth century, it has not had the effect of reducing the opportunities for small business in the nonagricultural sector of the economy. This finding does not, however, render it superfluous to investigate the trend in concentration. The degree to which economic activity is concentrated in large firms is obviously a very important aspect of the environment in which small business operates. Small firms deal with large firms as suppliers, customers, and competitors. Any change in the inequality. of size or in the number of alternative sources or outlets facing the small firm is bound to affect the way in which small business operates and the results of its operations.

\footnotetext{
17 Computed from data in NAM, Business Stze and the Public Interest 17 (I949).

${ }^{18}$ Computed from data in Survey of Current Business, April 1955, p. 20; id., Jan. I954, p. I3; id., Jan. 1958, p. 6 .
} 
The long-run trend in concentration has, in recent years, been the subject of a lively controversy in academic circles. In the 'thirties, the statistical investigations of Gardiner C. Means appeared to support the theory of a trend toward increasing concentration, and his opponents were mainly concerned to attack the reliability of his figures-always an easy task in this field. ${ }^{19}$ Since the war, new statistical studies suggest that in important sectors of the economy, concentration is more likely to have declined over the last fifty years, and it is now the protagonists of the theory of increasing concentration who attack the reliability of the statistics. ${ }^{20}$

The subject is controversial not only because the statistical information is inadequate and unreliable, but also because there is no agreement, and often no clarity, as to what is meant by "concentration" and how it should" be measured. In this paper, concentration will be discussed in two senses: "Absolute" concentration means the degree to which a small number of firms accounts for a large sector of the economy, industry, or product under discussion. "Relative" concentration, or "inequality," means the degree to which a small percentage of the firms concerned accounts for a large proportion of the economy, industry, or product. The terms "concentration" and "inequality," used without qualifying adjectives, will mean "absolute" and "relative" concentration, respectively.

The room for controversy is further enlarged by the fact that there is no unique way of measuring concentration or inequality. Concentration is often measured by the percentage of an industry's output accounted for by the four, eight, or twenty largest firms. But in a given period, an industry may become less concentrated in terms of the four largest firms and more concentrated in terms of the eight largest. Inequality can be measured by the percentage of, say, output controlled by the largest one per cent, five per cent, or ten per cent of the firms, as well as by a "coefficient of variation," a "Gini ratio," a "Pareto coefficient," and other fruits of the statistician's imagination. In the comparison of different industries or periods of time, it is quite possible for the verdict of these measures to disagree. ${ }^{21}$

Often, a particular development may have opposite effects on concentration and inequality. The recent mergers among the smaller automobile manufacturers left concentration unchanged, if measured in terms of the three largest firms, raised concentration in terms of four firms, and reduced the degree of inequality. Such a situation not only provides unlimited scope for controversy among those who discuss the trend in concentration without defining their terms, but also created a real

${ }^{19}$ See BerLe \& Means, op. cit. supra note 1, c. 3; Crum, On the Alleged Concentration of Economic Power, 24 AM. Econ. Rev. 69 (1934); Tucker, Increasing Concentration of Business Not Supported by Statistical Evidence, $4^{8}$ The Annalist 499 (1936); George, Is Big Business Getting Bigger?, Dun's Review, May r939, pp. 28, 32.

${ }^{20}$ See G. W. Nutter, The Extent of Enterprise Monopoly in the United States (i95i); Adelman, supra note 3; Edwards, Stocking, George, Berle, Four Comments on "The Measurement of Industrial Concentration," 34 Rev. Econ. \& STar. I56, I6r, r68, I72 (r952); Adelman, A Rejoinder, id. at 174, 356; Blair, "The Measurement of Industrial Concentration": $A$ Reply, id. at 343 .

${ }_{21}$ For a fuller discussion of problems involved in the measurement of concentration, see Rosenbluth, Measures of Concentration, in G. J. Stigler (ED.), Business Concentration and Price Policy 57 (1955). 
dilemma for antitrust policy, since competition was increased in a significant sense by the reduction in inequality and reduced by the increase in concentration.

Scope for controversy is further broadened by the variety of economic units for which concentration can be measured. Berle and Means studied the role of the 200 largest nonfinancial corporations in relation to all corporations, all "business wealth," and national wealth. Other studies have measured concentration within narrowlydefined industries or within broad industry classes. Obviously, the trend of concentration measured on an over-all basis may diverge from the trend in some sort of average of concentration levels measured within narrowly-defined industries. For our purposes, both bases of measurement are significant. For the study of the relations of small businesses with their competitors, the measurement of concentration within industries is appropriate. But the relations of small businesses with the suppliers of their materials, equipment, or credit and the purchasers of their products or services generally cut across industry lines.

Finally, there is, in theory at least, a considerable range of choice as to the units in which business size is to be measured for the purpose of studying concentration. Employment, value of output, net income, and assets have all been used; each of them involves a host of problems in the fields of measurement and valuation, and, again, it is theoretically quite possible for their verdicts to diverge.

If, in addition to all these difficulties, we consider the great paucity of relevant statistical information, it is not surprising that there has been controversy. What is, perhaps, surprising is that in relation to a number of important matters, there is agreement. We shall, therefore, start by considering those aspects of the trend in concentration that are not in dispute.

The first important point of agreement is that the economy emerged from the merger movement of the end of the nineteenth century with a very high degree of concentration in many important economic sectors. A recent survey of the literature on mergers sums it up thus: ${ }^{22}$

The early combination movement ... was of extraordinary social and economic importance. Historians have recorded it as an era and economists consider it the period when the pattern of concentration characteristic of twentieth-century American business formed and matured. . . . Of 92 large mergers studied by Moody, 78 controlled $5^{\circ}$ per cent or more of the total output of the industry. ... . In the steel, tobacco products, petroleum refining, sugar refining, nonferrous metal smelting, shoe machinery, typewriter and other industries, it is quite clear that mergers transformed oligopolistic or competitive markets into markets dominated by partial monopolists. ...

Many important aspects of this wave of mergers are still in dispute. There is a disagreement regarding the relative importance of the economies of mass production, the expectation of monopoly positions, and the search for "promoter's profit" in the motivation of the organizers of the giant combinations. There is also disagreement as to the extent to which monopoly positions were actually attained. But

\footnotetext{
${ }^{23}$ Markham, Survey of the Evidence and Findings on Mergers, in id. at I55, 158.
} 
there is no disagreement about the fact that concentration and inequality of firm size, for the economy as a whole and its major sectors, increased decisively.

These changes in the business size structure radically transformed the problems confronting small firms, which were subjected to a variety of pressures from their larger brethren. Even before the "major" merger wave of 1896-1903, farmersthe largest class of small businessmen-were reacting in the political field against their increasing dependence on the large railway companies for transportation, on manufacturing trusts for their equipment, and on giant food-handling and processing firms for their markets. The early state antitrust laws, the Sherman $\mathrm{Act}^{23}$ and the Interstate Commerce Act ${ }^{24}$ can be seen as the politicians' response to agrarian discontent. With the subsequent spread of concentration by merger throughout the manufacturing industries, as well as metal-mining and public utilities, the numerous small businessmen in manufacturing and retailing felt the pressure. The use of concentrated buying power to secure discriminatory prices from suppliers or railways, the practice of local price discrimination in selling to undermine a small competitor, selling below cost to eliminate a competitor, and all the other "unfair" competitive practices that were revealed in investigations and court proceedings before World War I (and repeatedly since that time) were all essentially devices used by the large against the small. They were "good business" only in a context of great inequality of market power and financial resources. The agitation against them, which led to the Clayton $\mathrm{Act}^{25}$ and the Federal Trade Commission Act, ${ }^{26}$ owes its success to the political weight of small business.

The secondi point on which there is agreement is that there has been wide diversity in the trends displayed by different industries since that great merger wave. It is easy to find important examples of increasing concentration. The automobile industry emerged from the early period of consolidation with the three leading firms accounting for forty-two per cent of car production. This figure is for 1909 , one year after the General Motors merger. By 1920, the three largest firms accounted for seventy-one per cent of output, as a result of the spectacular success of Ford's mass production technique, which raised the share of this company alone to fortynine per cent. After the Chrysler merger in 1925, the share of the three largest firms continued to rise, although Ford's share declined. On the basis of new car registrations, the three largest firms accounted for seventy-two per cent in r925, eighty-three per cent in 1930 , and ninety per cent in $1938 .{ }^{27}$ The proportion was lower immediately after the war, but had reached ninety-five per cent by $1955 .{ }^{28}$

${ }^{28} 26$ STAT. 209-10 (I890), as amended, 15 U.S.C. \$\$ I-7 (1952).

2h 24 STAT. 379 (1887), as amended, 49 U.S.C. \$\$ I-27, 4I-43, 30r-27 (1952).

${ }^{25} 38$ STAT. 730 (19I4), 15 U.S.C. $\$ \$$ II-27 (1952).

${ }^{20} 38$ STAT. 717 (1914), as amended, I5 U.S.C. \$\$ 41-58 (1952).

27 Willard L. Thorp, Walter F. Crowder, and Associates, The Structure of Industry 244 (TNEC Monograph No. 27, 194I).

${ }^{28}$ FTC, Report on Industrual Concentration and Product Diversification in the jooo Latgest Manufacturang Companies it3 (1957). 
Other examples of large industries with increasing concentration, at least in the last twenty years, are the brewing industry, where the share of output of the eight largest firms rose from seventeen per cent in 1935 to forty-one per cent in 1954; and the flour-milling industry, in which the eight largest firms accounted for thirty-seven per cent of output in I935 and fifty-two per cent in $1954^{29}$ In copper production, the share of the four leading producers fell from seventy-six per cent in I8go to thirtynine per cent in I920. Subsequently, however, concentration increased again very rapidly, and the four leading producers accounted for seventy-six per cent of copper output in I930 and eighty-two per cent in 1937. In I954, the four leading producers accounted for ninety-four per cent of the output of copper smelter products. ${ }^{30}$

On the other hand, we can find many important industries in which concentration has continued to decline from the high levels reached at the turn of the century. For example, the four largest meat-packing firms were reported to control fifty per cent of the industry or more at the turn of the century. ${ }^{31}$ By 1947 , the share of the four largest had fallen to forty-one per cent, and by 1954, to thirty-nine per cent. $^{32}$ The Standard Oil trust, before its dissolution by court decree, controlled the marketing of about eighty per cent of refinery production. As a result of the dissolution in Igrr and the entry of new firms, concentration declined considerably, and in 1938 , the twenty leading firms held only seventy-three per cent of refinery capacity, and the four leading firms held twenty-seven per cent. ${ }^{33}$ A further decline in concentration is indicated by the data for the value of output of the refinery industry: concentration of output in the four largest firms fell from thirty-eight per cent in 1935 to thirty-three per cent in $19544^{34}$

An analysis of concentration trends in 123 manufacturing industries shows that in the nineteen years, $1935-54$, concentration of output in the four largest firms increased by ten percentage points or more in fourteen per cent of the cases, and decreased by ten percentage points or more in twenty-three per cent of the cases. Increases of five percentage points or more accounted for just under one-third of the cases, and decreases of five percentage points or more for just over one-third. ${ }^{35}$ It is clear, therefore, that any average of concentration trends within industries represents the net effect of conflicting tendencies, and that there has been no typical pattern of increase or decrease. It is not surprising, then, that estimates of the "average" increase or decrease in concentration within industries have been small.

The third point on which there is agreement, at least among the postwar investigators of the trend in concentration, is that any change in absolute "over-all"

${ }^{20}$ Staff of Subcommittee on Antitrust and Monopoly, Senate Comm. on the Judiciary, 85th Cong., ist Sess., Concestration in American Industry 221 (Comm. Print 1957) [hereinafter cited as Concentration in AMrerican INDUSTRy].

${ }^{80}$ Thorp \& Crowder, op. cit. supra note 27, at 249; Concentration in American Industry 83.

${ }^{32}$ NutTER, op. cit. supra note 20, at 130 .

so Concentration in American Indestry ig6.

${ }^{3}$ H. L. Purdy, M. L. Lindafi, \& W. A. Carter, Corporate Concentration and Public Policy 253,258 (I950).

is Concentration in AMerican Industry 207.

${ }^{85}$ Id. at 35 . 
concentration, for the economy as a whole or its major sectors, has probably been slight. It is safe to assume that a strong trend of increasing or decreasing concentration would have been less open to controversy.

A review of some of the statistical information on over-all concentration will indicate the order of magnitude of the possible changes. The long-run trend in manufacturing is indicated by Kaplan's data on the role of the roo largest "industrial" corporations. As a percentage of the corresponding total for all industrial corporations, the total assets of the roo largest amounted to 24.6 per cent in $1909,25.5$ per cent in 1929 , and 26.7 per cent in $194^{36} .^{36}$

For the latter part of this period, more detailed information is available which is summarized in table two. These figures suggest that in the last twenty years, overall concentration in manufacturing has not changed much, although there may have been a slight increase in the last decade.

In the public utilities field, never a significant area for "small business," concentration increased up to the 'thirties, largely as a result of the "second merger wave" of the late 'twenties. That is why Means' figures for the "200 largest nonfinancial corporations," including railways and public utilities, showed an increase in concentration. In terms of total "net" assets (excluding investment in other corporations) and in relation to all "nonfinancial" corporations, concentration in the 200 largest rose from about one-third in I909 to about one-half in I929, and fifty-five per cent in $1933 .{ }^{37}$ Subsequently, however, the public utilities industry has been "deconcentrated" under the provisions of the Public Utility Holding Company Act of I935..$^{38}$

In the transportation sector, there has been a steady increase of concentration in the railway branch; the number of operating railway companies fell from 1306 in rgro to 775 in 1930 , and $47 \mathrm{I}$ in $195^{0.39}$ This development has, however, been accompanied (and, indeed, in part caused) by the rapid expansion of road, and later, air transportation; and the net effect has undoubtedly been a decline in concentration for the sector as a whole. By the beginning of World War II, the railways' share of intercity domestic freight traffic (in ton-miles) was less than two-thirds. After a brief upswing in the war, it fell to fifty-eight per cent in 1950 , and below fifty per cent in I954. The share of road transport rose from nine per cent in 1939 to nineteen per cent in 1954; and the share of oil pipelines from ten per cent in I939 to sixteen per cent in $1954 .^{40}$

Complaints of increasing concentration in the retail field were frequent in the 'twenties and 'thirties and were a prominent feature of the political campaign that

${ }^{\text {se }}$ A. D. H. Kaplan, Big ENterprise in a Competitive System 126 (I954). "Industrials" exclude financial, railway, and public utility corporations. Corporations in mining, construction, trade, and services are included, but manufacturing accounts for about $2 / 3$ of the total "industrial" assets.

${ }^{37}$ Nat'z Resources Comm., The Structure of the American Economy pt. I, at ro6.07 (1939).

${ }^{38} 49$ Stat. 803 , 15 U.S.C. $\$ \$ 79-79 z-6$ (1952).

${ }^{89}$ Statistical Abstract 561.

10 Id. at 559. 
culminated in the Miller-Tydings Act. ${ }^{41}$ Statistics available since I929 suggest that there was some justification for these claims; the percentage of retail sales accounted for by chain stores and mail-order houses rose from twenty-one per cent in I929 to twenty-seven per cent in I933, and had probably risen in the preceding decade. Since the 'thirties, however, there does not seem to have been any rising trend in this percentage; it was twenty-three per cent in I939 and twenty-two per cent in 1951. Since that latter year, a new statistical series based on a narrower definition of "chain stores" shows a slight increase in the corresponding percentage from eighteen per cent in $195^{1}$ to nineteen per cent in $195^{6}$. The increase has been somewhat more pronounced in the grocery field, where the chain stores' percentage of business rose from thirty-five per cent in I95 to thirty-nine per cent in $195^{6 .{ }^{42}}$

Agriculture is the only economic sector that provides clear evidence of a steady trend towards higher concentration. In I920, the 2I7,200 largest farms (of a total of 6,400,000) accounted for thirty-four per cent of the acreage; and in r940, only I00,500 farms accounted for the same percentage. By I950, the 121,400 largest farms had forty-three per cent of the acreage. The number of farms diminished throughout this period, while the total acreage increased. ${ }^{43}$

No comprehensive information on the trend in concentration is readily available for the other sectors of the economy. The main nonfinancial sectors-construction,

TABLE II

Concentration in Manufacturing

A. Percentage of Value of Output

\begin{tabular}{|c|c|c|}
\hline 1935 & 1937 & r950 \\
\hline 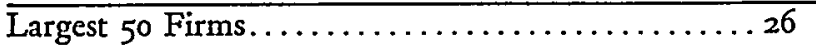 & 28 & 27 \\
\hline 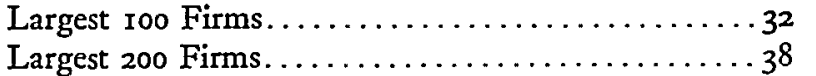 & $\begin{array}{l}34 \\
4 \mathrm{I}\end{array}$ & $\begin{array}{l}33 \\
40.5\end{array}$ \\
\hline
\end{tabular}

B. Percentage of Value Added by Manufacture

\begin{tabular}{|c|c|c|c|}
\hline 1935 & $x 937$ & 1947 & I954 \\
\hline Largest 50 Firms............ & $20^{a}$ & I7 & 23 \\
\hline Largest 10o Firms.............. 25 & $26^{a}$ & 23 & 30 \\
\hline Largest 200 Firms........... & $32^{\mathrm{a}}$ & 30 & 37 \\
\hline
\end{tabular}

a Ranking of firms based on value of output; hence the percentage may be slightly understated.

Sources: A. FTC, Report on Changes in Concentration in Manufacturing, I935 to I947, and 1950, at I7, 2 (r954); Willard L. Thorp, Waiter F. Crowder, and Associates, The StrticTURE OF INDUSTRY 715 (TNEC Monograph No. 27, 194I).

B. Staff of Subcommittee on Antrtrust and Monopoly, Senate Comm. on the Judiciary, 85th Cong., 2d Sess., Concentration in American Industry it (Comm. Print x957); Willard L. Thorp, Walter F. Crowder, and Assoctates, The Structure of Industry 583, 7I5 (TNEC Monograph No. 27, 1941); Nat'l Resources Comm., The Structure of THE AMERICAN ECONOMY pt. I, 270 (I939).

41 50 STAT. 693 (1937), I5 U.S.C. \$ I (1952).

${ }^{4}$ Statistical Amstract 838,849; Adelman, The Measurement of Industrial Concentration, 33 Rev. ECoN. \& STAT. 269, 293 (195I).

“s Statistical Abstract 622. 
mining, services, and wholesale trade-are, of course, included in Kaplan's data for the leading "industrial" corporations cited above.

The financial sector has generally been ignored by the participants in the recent debate on the trend in concentration. Yet, for banking, sufficiently reliable information is available, which indicates a decline in concentration to about 1920, a definite rise to I940, and some decline thereafter. Between I900 and I920, the number of banks rose from 10,382 to 30,139 , and the percentage of total loans and investments held by the twenty largest banks fell from I5.I per cent to I3.8 per cent. In 1920, fifty-nine per cent of all commercial banks had a capital stock of less than $\$ 50,000$ and could thus be classified as "small business." Thereafter, under the impact of mergers and failures, concentration increased rapidly. By 1930, the number of banks had fallen to 24,079 , and the percentage of loans and investments concentrated in the twenty largest banks had risen to 24.8 per cent. Following the widespread failures of the early 'thirties, the number of active banks fell to 16,053 in $1935 .{ }^{44}$ Concentration of deposits in the roo largest commercial banks rose from forty-six per cent in I930 to fifty-five per cent in I935, and fifty-eight per cent in $19400^{45}$

In the 'forties and the 'fifties, the number of banks has continued to shrink-to 14,666 in 1950 and 14,103 in $1957^{46}$ Nevertheless, concentration appears to have declined from the peak level reached in 1940. In 1948, the roo largest commercial banks held only forty-five per cent of the deposits of all commercial banks. Since then, the proportion has increased slightly, but not enough to indicate a trend; in 1955, it was still only forty-seven per cent. ${ }^{47}$

The figures given here understate the degree of concentration in banking, owing to the existence of groups of banks under common control. The number of such groups and of banks under their control rose rapidly in the 'twenties. In I925, there were 134 groups or chains operating 933 banks, while in 1929, there were 33I groups with r921 banks. By I952, the number of banks in groups or chains had fallen to 909, largely owing to an increase in the number of states permitting branch banking. ${ }^{48}$ Thus, the decline of concentration of control since the 'thirties has probably been greater than the decline in concentration in banks considered as separate units.

This survey of concentration trends can now be summed up. The trend in agriculture has followed; the pattern asserted by the theory of increasing concentration, and the number of small firms has declined. In the nonagricultural sector, however, the number of small firms has increased, and concentration in individual narrowlydefined industries has shown a variety of patterns. Over-all concentration in the

«A. L. Bernstein (Ed.), Big Business, Its Growth and Place 83, 91,92 (1937); and Statistical ABSTRACT 438.

${ }^{45}$ Select Committee on Small Business of the Senate, 82d Cong., 2d Sess., Concentration of Banking in the United States 16 (Comm. Print No. 7, 1952) [hereinafter cited as Concentration of BankING].

10 88th An. Report of the Comptroller of the Currency I4 (1951); id. 95th, at i9-20 (1958).

4 Concentration of Banking 16; Hearings Before the Committee on Banking and Currency of the Senate on Regulation of Bank Mergers, 84th Cong., 2d Sess. 17 (1956).

${ }^{48}$ See P. T. Hogenson, The Economics of Group Banking, 13, 15-17 (1955); Concentration of BANRING 7, 8. 
major branches for which information is available does not seem to have changed much since the pattern of high concentration was established at the turn of the century. If a statement one way or the other must be made on the basis of the figures we have examined, some increase over the long run is suggested in manufacturing, distribution, and banking; but, taking into account the difficulties discussed at the beginning of this section, one cannot say that the data are inconsistent with the assumption that there has been no change, or even a slight decline, in overall concentration. There has certainly not been any strong decline or, for that matter, any strong increase.

Coming back to the controversy outlined in the introduction, it looks as if the prize should be awarded to the opponents of the theory of increasing concentration. Concentration, over-all, has not increased (greatly, at any rate) if we ignore agriculture (which is common practice), and the number of small firms definitely has increased (again, if we ignore agriculture). There is, however, an important corollary of these results that is often overlooked. If the number of firms in the nonagricultural sector has increased significantly, and the degree of absolute concentration has not declined greatly, then the degree of relative concentration or inequality must (this is a mathematical "must") have increased. If the share of the largest 200 firms, say, has not changed, and the number of firms has increased, this share is now held by a smaller percentage of the firms. Or, putting the matter differently, the ratio of the average size of the largest 200 firms to the average size of all firms has increased. As far as the problems confronting small business are concerned, this increase in inequality of size, which has continued throughout the period reviewed here, is, of course, very important. The large firms have grown larger, and the small firms more numerous.

\section{IV}

\section{Why Small Business Survives}

It is, perhaps, surprising that the same environment that has encouraged the growth of large firms has also been favorable to the multiplication of small firms. At any rate, it is surprising to those whom a training in economic theory has conditioned to consider these developments as incompatible.

Two related types of development have, over the last fifty years, repeatedly created and expanded opportunities for small business. First, technological progress has developed new techniques and products that could be profitably exploited by small business. Secondly, the trend has been reinforced by a tendency for large firms to free themselves of functions that could be economically performed by the small.

Examples of these trends have often been discussed. On the purely technological side, the advent of electric power has freed the firm from the heavy overhead involved in generating its own power; has increased the range of economical plant locations, thus lowering initial costs; and has made possible the development of 
efficient low-capacity machinery. The light metals and plastic materials that are becoming increasingly important have proved suitable for secondary fabrication in small-scale plants. Road transport not only has opened opportunities for small firms in trucking and bus transportation, but has also contributed to the scattering of plant locations. Many developments in processing technique have favored small firms. ${ }^{40}$ Thus, the very common assumption that technological progress must involve increasing economies of scale is not correct.

These technological trends have been reinforced by opportunities for small business created by the growth of large firms. Small business has been driven out of the manufacture of automobiles, but has found greater opportunities in the sale of automobiles. Conversely, supermarket chains and mail-order houses have provided outlets for a host of small manufacturers and new classes of wholesalers. Such new types of small business as the advertising agency, management consultant, and research service in marketing, economics, sociology, and psychology sell their services to the large corporation. Thus, many small businesses exist today which would have no place in a small-business economy. They depend on inequality of size for their existence. Thus, to some extent, small firms have grown more numerous because large firms have grown larger.

\section{IMPLICATIONS}

The role of small business and the problems confronting it in an economy marked by extreme and growing inequality of firm size are quite different from those that would arise in a small-business economy. Many small businesses today are little more than appendages of the large. An automobile dealer who obtains all his stock from one manufacturer, a gasoline dealer who obtains not only his supplies, but also his financing and capital equipment from one firm, a manufacturer who sells his whole output to one mail-order house, an advertising agency or consulting service that gets ninety-eight per cent of its business from one firm-all these can hardly be regarded as "independent businessmen" in the traditional sense. In the less extreme cases, the small businessman is faced with high concentration in the sources of his materials, his equipment, or his financing, or high concentration among the buyers of his product or service. The resulting inequality of bargaining power means a loss of independence. When a small businessman is in competition with larger rivals, there is likely to be price discrimination in their favor and discrimination in the allocation of scarce supplies and in financing. In a world in which contracts with government agencies are of increasing importance, large business tends to get the contracts and small business the subcontracts. As the trend has been towards increasing inequality of size, the problems arising from inequality are likely to have become more widespread and more serious.

${ }^{\iota}$ See Blair, Technology and Size, $3^{8}$ AM. Econ. REv. I2I (1948). The examples cited are based on this article. 
A good deal of legislative effort has gone into attempts to protect small business against the consequences of inequality and concentration. Some, such as the antitrust laws and the attempts to reduce discrimination in financing, tend to promote competition and economic efficiency. Others, such as the legalization of resale price maintenance and the agricultural price supports, marketing quotas, and acreage allotments, have the opposite effect. This is not the place for an evaluation of these policies, but one comment may, perhaps, be permitted. The traditional notion that small business is "a good thing," quite apart from the question of competitive efficiency, is based on certain political, psychological, and sociological assumptions. The diffusion of economic power in a society of small businessmen has been regarded as a safeguard against the concentration of political power. The training in the exercise of independent judgment and in reliance on one's own decisions has been considered good for the soul. The widespread ownership of property and interest in the continuity of business relations has been seen as an element of social stability. It is necessary to re-examine such assumptions as these in the context of the actual structure and functioning of the business economy. 